\title{
Profil Mikroorganisme Penyebah Sepsis Neonatorum di Departemen IImu Kesehatan Anak Rumah Sakit Cipto Mangunkusumo Jakarta
}

\author{
Anita Juniatiningsih, Asril Aminullah, Agus Firmansyah \\ Departemen Ilmu Kesehatan Anak FKUI, Rumah Sakit Cipto Mangunkusumo, Jakarta
}

\begin{abstract}
Latar belakang. Angka morbiditas dan mortalitas sepsis neonatorum (SN) masih tinggi. Pemberian antibiotik sesuai dengan hasil kultur diperlukan untuk mencegah resistensi kuman terhadap antibiotik.

Tujuan. Mengetahui profil mikroorganisme penyebab SN serta sensitivitasnya terhadap antibiotik di Departemen Ilmu Kesehatan Anak Rumah Sakit Cipto Mangunkusumo (IKA-RSCM) Jakarta

Metode. Studi potong lintang, dilakukan di ruang rawat Divisi Perinatologi Departemen IKA, pada Desember 2006 - Juli 2007, pada neonatus tersangka sepsis untuk pertama kalinya, belum pernah mendapat antibiotik sebelumnya, tidak terdapat kelainan kongenital mayor dan mendapat persetujuan dari orang tua.

Hasil. Terdapat 334 kasus tersangka SN, 102 kasus di antaranya memenuhi kriteria inklusi dan dapat dianalisis. Empat puluh dua kasus $(41,2 \%)$ memiliki biakan darah positif. Mikroorganisme penyebab SN terbanyak adalah bakteri gram negatif seperti Acinetobacter calcoaceticus, Enterobacter aerogenes, Pseudomonas $s p$ dan Eschericia coli. Bakteri gram negatif mempunyai sensitivitas yang rendah terhadap antibiotik lini pertama dan kedua, kecuali Enterobacter aerogenes yang masih sensitif terhadap gentamisin dan Pseudomonas yang masih sensitif terhadap seftazidim. Sensitivitas bakteri gram positif dan negatif umumnya masih sangat baik terhadap meropenem. Sensitivitas bakteri gram negatif cukup baik terhadap imipenem namun bakteri gram positif kurang sensitif terhadap imipenem.

Kesimpulan. Etiologi SN umumnya adalah bakteri gram negatif dengan isolat terbanyak Acinetobacter calcoaceticus. Umumnya bakteri gram negatif mempunyai sensitivitas yang rendah terhadap antibiotik lini pertama dan kedua, kecuali Enterobacter aerogenes yang masih sensitif terhadap gentamisin dan Pseudomonas terhadap seftazidim. (Sari Pediatri 2008;10(1):60-5).
\end{abstract}

Kata kunci: sepsis neonatorum, mikroorganisme, uji resistensi

Alamat Korespondensi:

Prof. Dr. Asril Aminullah Sp. A (K). Divisi Perinatologi, Departemen Ilmu Kesehatan Anak FKUI/RSCM, Jl. Salemba 6, Jakarta 10430,

Telp.3146811,3918301 ext 3133. Email: asrida@dnet.net.id 
S epsis neonatorum masih merupakan masalah di bidang perinatologi. Seperti dikutip oleh Aminullah ${ }^{1}$, World Health Organization menyatakan case fatality rate sepsis neonatorum masih tinggi. Diagnosis tidak mudah karena gejala dan tandanya tidak spesifik. Angka kejadian sepsis neonatorum di Amerika Serikat 1-5 kasus/1000 kelahiran hidup. ${ }^{2}$ Di Divisi Perinatologi Departemen IKA-RSCM kejadian sepsis neonatorum $15,5 \%$ dari kelahiran hidup, ${ }^{3}$ pada Januari-September 2005 kematian mencapai 13,68\%. ${ }^{4}$

Bakteri, virus, jamur dan protozoa dapat menyebabkan sepsis. ${ }^{5,6}$ Di negara maju sepsis awitan dini (terjadi dalam 72 jam setelah kelahiran ${ }^{5,7}$ ) biasa disebabkan oleh Streptokokus grup B, kuman gram negatif terutama Eschericia coli, Listeria monocytogenes, dan Haemophilus influenzae. ${ }^{2,5,8,9}$ Sepsis awitan lambat (terjadi setelah 72 jam kehidupan ${ }^{10}$ ) biasa disebabkan oleh Coagulase Negative Staphylococci, Staphilococcus aureus, Eschericia coli, Klebsiella, Pseudomonas, Enterobacter, Candida, Serratia, Acinetobacter dan kuman anaerob. ${ }^{8}$ Di Divisi Perinatologi Departemen IKA-RSCM (2002) etiologi tidak banyak berbeda pada sepsis awitan dini maupun lambat, yaitu Enterobacter sp, Klebsiella sp. dan Acinetobacter sp. ${ }^{11}$

Pemberian antibiotik sesuai dengan hasil biakan penting untuk mencegah resistensi kuman terhadap antibiotik, sehingga perlu pendataan mikroorganisme penyebab sepsis secara berkala untuk membuat protokol pemilihan antibiotik yang tepat. Tujuan penelitian adalah mengetahui profil mikroorganisme penyebab sepsis neonatorum di Departemen IKARSCM Jakarta serta resistensi terhadap antibiotik.

\section{Metode}

Studi potong lintang dilakukan di ruang rawat Divisi Perinatologi Departemen IKA-RSCM pada 18 Desember 2006 - 3 Juli 2007. Kriteria inklusi adalah neonatus tersangka sepsis yang dirawat di RSCM, teridentifikasi tersangka sepsis untuk pertama kalinya, belum pernah mendapat antibiotik sebelumnya, akan dilakukan septic work-up yaitu pemeriksaan darah perifer (hemoglobin, hematokrit, hitung leukosit, hitung trombosit), rasio IT (rasio imatur/total neutrofil), CRP (C-reactive protein) dan biakan darah serta mendapat persetujuan orang tua. Neonatus dengan kelainan kongenital mayor tidak diikutsertakan. Kriteria tersangka sepsis sesuai dengan protokol Divisi Perinatologi Departemen IKA (klinis, faktor risiko dan laboratorium dasar). Sampel diambil secara consecutive sampling. Pemeriksaan darah perifer dan CRP $( \pm 0,5 \mathrm{~mL})$ dilakukan di laboratorium Divisi Perinatologi, sampel darah untuk kultur $(1 \mathrm{ml})$ dalam media transpor $\left(\right.$ BacT/Aler $\left.{ }^{\circledR} P F\right)$ diperiksa di laboratorium Patologi Klinik RSCM. Sampel darah diambil oleh tenaga kesehatan terlatih. Ethical clearance dari Panitia Tetap Penilai Etik Penelitian Fakultas Kedokteran Universitas Indonesia telah diperoleh dan informed consent pada orang tua subjek telah dilakukan. Data diolah dengan SPSS version 12.00.

\section{Hasil}

Pada periode Desember 2006 - Juli 2007 terdapat 2296 neonatus yang dirawat di Divisi Perinatologi baik yang lahir di RSCM maupun di luar RSCM dan terdapat 334 neonatus tersangka sepsis untuk pertama kalinya dengan hasil biakan darah positif 148 kasus $(44,3 \%)$. Dari 334 kasus tersebut 117 kasus memenuhi kriteria inklusi, 15 kasus dikeluarkan dari penelitian karena ketidaklengkapan data, sehingga terdapat 102 kasus yang dapat dianalisis dengan hasil kultur darah positif sebanyak 42 kasus $(41,2 \%)$.

\section{Karakteristik subjek penelitian}

Rerata umur subjek adalah 1,83 hari (SD 5,16) dengan median 0 hari (rentang 0-28 hari). Rerata berat lahir adalah 2330 gram dengan median 2500 gram (rentang 900-4120 gram). Rerata usia gestasi adalah 35 minggu (SD 4,09) dengan median 37 minggu rentang 7-42 minggu). Sebagian besar subjek lahir dengan berat 2500 gram (52 bayi=51\%), 50 bayi lainnya (49\%) tergolong bayi dengan berat lahir rendah (<2500 gram) dengan 20 bayi di antaranya $(19,6 \%)$ bayi dengan berat lahir sangat rendah (<1500 gram). Sebagian besar subjek ( 54 bayi $=52,9 \%$ ) tergolong neonatus cukup bulan (usia gestasi 37 minggu-42 minggu) dan sisanya (48 bayi $=47,1 \%$ ) neonatus kurang bulan. Enam puluh dua subjek laki-laki, 23 di antaranya terbukti sepsis dan 40 subjek perempuan, 19 di antaranya terbukti sepsis. Tidak terdapat perbedaan statistik yang bermakna antara jenis kelamin dengan sepsis terbukti $(p=0,297$, rasio odss 0,652 , IK 95\%=0,291-1,46). Delapan puluh sembilan subjek $(87,3 \%)$ termasuk tersangka 
sepsis awitan dini dan hanya 13 subjek (12,7\%) yang termasuk tersangka sepsis awitan lambat.

Sebagian besar subjek (52,9\%) berasal dari ruang rawat di Instalasi Gawat Darurat (IGD) lantai 3 (ruang rawat transisi setelah neonatus lahir di ruang bersalin), diikuti 31,3\% subjek dari luar RSCM melalui IGD lantai 1. Sisanya berasal dari CMU lantai 3 (ruang rawat baru yang dibuka pada 2 Mei 2007) dan IRNA A lantai 3 (ruang rawat gabung) (Tabel 1).

Tabel 1. Sebaran neonatus tersangka sepsis berdasarkan tempat perawatan Divisi Perinatologi saat diagnosis tersangka sepsis ditegakkan pertama kali dibandingkan dengan hasil kultur darah positif (sepsis terbukti)

\begin{tabular}{lccc}
\hline \multirow{2}{*}{$\begin{array}{c}\text { Tempat } \\
\text { perawatan }\end{array}$} & \multicolumn{2}{c}{ Sepsis terbukti } & Total \\
\cline { 2 - 3 } & ya & tidak & \\
\hline IGD lantai 1 & 13 & 19 & 32 \\
IRNA A lantai 3 & 3 & 1 & 4 \\
IGD lantai 3 & 24 & 30 & 54 \\
CMU lantai 3 & 2 & 10 & 12 \\
\hline Total & 42 & 60 & 102 \\
\hline
\end{tabular}

Tabel 2. Gejala/tanda klinis tersering pada neonatus tersangka sepsis*

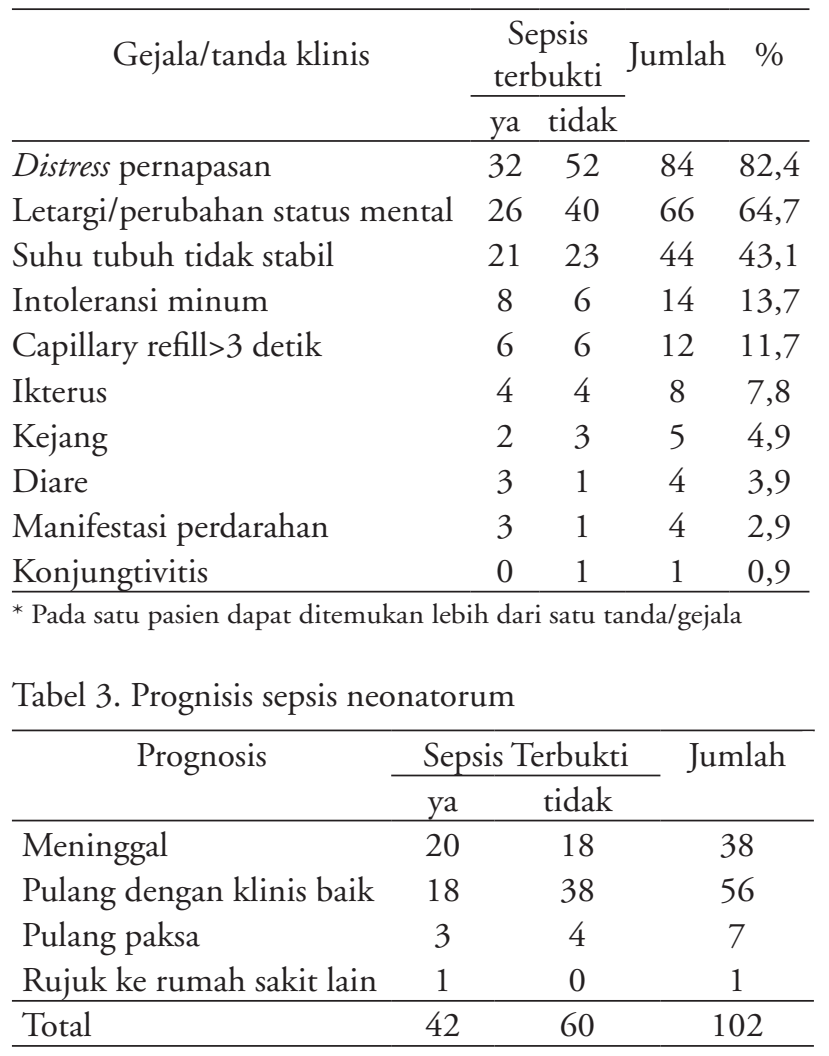

Sebagian besar subjek mengalami distress pernapasan, dan sebagian kecil mengalami ikterus, kejang, diare maupun manifestasi perdarahan seperti perdarahan saluran cerna, petekie/purpura (Tabel 2).

Dari 20 subjek terbukti sepsis yang meninggal $(47,6 \%) 14$ berasal dari IGD lantai 3, 4 dari IGD lantai 1,1 dari IRNA A lantai 3 dan 1 dari CMU lantai 3 (Tabel 3).

\section{Profil mikroorganisme penyebab sepsis neonatorum}

Penyebab sepsis pada penelitian ini umumnya adalah bakteri gram negatif seperti Acinetobacter calcoaceticus, Enterobacter aerogenes, Pseudomonas sp dan Eschericia coli. Sepsis awitan dini pada penelitian ini terbanyak disebabkan oleh bakteri gram negatif $(80,5 \%)$ sedangkan pada sepsis awitan lambat ditemukan bakteri gram positif dan negatif dalam jumlah yang hampir sama. Dua subjek dengan kultur darah Candida tropicalis dan sel ragi ditemukan pada sepsis awitan lambat (Tabel 4).

Pola sensitivitas mikroorganisme penyebab sepsis dianalisis terhadap 4 kelompok antibiotik. ${ }^{12}$ Tabel 5 menunjukkan bahwa bakteri gram negatif mempunyai sensitivitas yang rendah terhadap antibiotik lini pertama, kecuali Enterobacter aerogenes yang masih sensitif terhadap gentamisin. Sensitivitas bakteri gram positif bervariasi $(0-71,4 \%)$. Terhadap antibiotik lini

Tabel 4. Jenis mikroorganisme penyebab sepsis neonatorum $(\mathrm{n}=102)$

\begin{tabular}{|c|c|c|c|c|}
\hline \multirow{2}{*}{ Jenis mikroorganisme } & \multicolumn{2}{|c|}{ Awitan sepsis } & \multirow{2}{*}{ Jumlah } & \multirow{2}{*}{$\%$} \\
\hline & $\operatorname{dini}$ & lambat & & \\
\hline Acinetobacter calcoaceticus & 15 & 0 & 15 & 14,7 \\
\hline Staphylococcus epidermidis & 5 & 2 & 7 & 6,9 \\
\hline Enterobacter aerogenes & 5 & 0 & 5 & 4,9 \\
\hline Pseudomonas sp & 4 & 0 & 4 & 3,9 \\
\hline Eschericia coli & 2 & 2 & 4 & 3,9 \\
\hline Klebsiella pneumoniae & 2 & 0 & 2 & 2 \\
\hline Klebsiella sp & 1 & 0 & 1 & 1 \\
\hline Proteus mirabilis & 0 & 1 & 1 & 1 \\
\hline Streptococcus viridans & 1 & 0 & 1 & 1 \\
\hline Streptococcus anhemolyticus & 1 & 0 & 1 & 1 \\
\hline Candida tropicalis & 0 & 1 & 1 & 1 \\
\hline Sel ragi & 0 & 1 & 1 & 1 \\
\hline Steril & 53 & 6 & 59 & 57,8 \\
\hline Total & 89 & 13 & 102 & 100 \\
\hline
\end{tabular}


Anita Juniatiningsih dkk: Profil Mikroorganisme Penyebab Sepsis Neonatorum

Tabel 5. Sensitivitas mikroorganisme penyebab sepsis neonatorum terhadap antibiotik

\begin{tabular}{|c|c|c|c|c|c|}
\hline \multirow[b]{2}{*}{ Antibiotik } & \multicolumn{5}{|c|}{ Sensitivitas terhadap antibiotik (\%) } \\
\hline & $\begin{array}{l}\text { Acinetobacter } \\
\text { calcoaceticus }\end{array}$ & $\begin{array}{l}\text { Staphylococcus } \\
\text { epidermidis }\end{array}$ & $\begin{array}{c}\text { Enterobacter } \\
\text { aerogenes }\end{array}$ & $\begin{array}{c}\text { Eschericia } \\
\text { coli }\end{array}$ & Pseudomonas sp. \\
\hline \multicolumn{6}{|l|}{ Lini pertama } \\
\hline Ampisilin & 0 & 0 & 20 & 0 & 0 \\
\hline Ampisilin sulbaktam & 15,3 & 71,4 & 20 & 0 & 0 \\
\hline Gentamisin & 33,3 & 66,6 & 100 & 0 & 0 \\
\hline \multicolumn{6}{|l|}{ Lini kedua } \\
\hline Amikasin & 25 & 100 & 50 & 50 & 33,3 \\
\hline Seftazidim & 78,6 & 0 & 40 & 25 & 100 \\
\hline Amoksisilin klavulanat & 0 & 75 & 25 & 0 & 25 \\
\hline Sefotaksim & 0 & 0 & 50 & 33,3 & 0 \\
\hline Seftriakson & 0 & 66,6 & 50 & 0 & 0 \\
\hline \multicolumn{6}{|l|}{ Lini ketiga } \\
\hline Sefepim & 33,3 & 66,6 & 100 & 75 & 33,3 \\
\hline Meropenem & 100 & 100 & 100 & 100 & 100 \\
\hline Imipenem & 75 & 50 & 100 & 100 & 100 \\
\hline \multicolumn{6}{|l|}{ Lini keempat } \\
\hline Kloramfenikol & 71,4 & 71,4 & 40 & 0 & 75 \\
\hline Siprofloksasin & 100 & 60 & 100 & 66,6 & 66,6 \\
\hline \multicolumn{6}{|l|}{ Lain-lain } \\
\hline Piperasilin tazobactam & 88,9 & 75 & 100 & 100 & 50 \\
\hline Kotrimoksazol & 81,2 & 42,9 & 33,3 & 25 & 60 \\
\hline Kanamisin & 16,7 & 57,1 & 80 & 0 & 0 \\
\hline
\end{tabular}

kedua umumnya bakteri gram negatif dan gram positif memiliki sensitivitas yang rendah, kecuali sensitivitas Staphylococcus epidermidis masih sangat tinggi terhadap amikasin (100\%) dan Pseudomonas masih cukup tinggi terhadap seftazidim (100\%). Sensitivitas bakteri gram positif dan negatif umumnya masih sangat baik terhadap meropenem (100\%). Sensitivitas bakteri gram negatif cukup baik terhadap imipenem (75$100 \%)$ namun bakteri gram positif kurang sensitif terhadap imipenem. Terhadap sefepim sensitivitas gram negatif bervariasi $(33,3 \%-100 \%)$, sedangkan sensitivitas bakteri gram positif sedang. Sensitivitas bakteri gram negatif maupun gram positif terhadap antibiotik lini keempat kloramfenikol bervariasi (0$75 \%)$, sedangkan terhadap siprofloksasin masih cukup baik (60-100\%).

\section{Diskusi}

Bayi laki-laki 1,5 kali lebih banyak menderita sepsis daripada bayi perempuan walaupun pada pembuktian dengan biakan darah tidak bermakna. Menurut kepustakaan sepsis lebih sering terjadi pada bayi lakilaki daripada perempuan. ${ }^{5,9}$ Yuliana $^{13}$ di RS Hasan Sadikin, Bandung mendapatkan hal yang sama dengan rasio 3,4 kali. Pada penelitian kami hampir 50\% bayi tersangka sepsis lahir dengan berat lahir rendah dan 47,1\% lahir dengan usia gestasi $<37$ minggu. Kepustakaan juga menyatakan bahwa prematuritas dan berat lahir rendah merupakan faktor risiko sepsis., ${ }^{5,9}$

Gejala/tanda klinis sepsis tersering pada penelitian ini adalah distress pernapasan, letargi dan suhu tidak stabil (hipotermia/hipertermia). Ikterus, kejang, diare, perdarahan dan konjungtivitis jarang ditemukan karena umumnya pasien terdiagnosis tersangka sepsis pada tahap yang dini. Selama perawatan $47,6 \%$ bayi yang terbukti sepsis (20 subjek) meninggal, lebih tinggi presentasinya dibandingkan angka kematian akibat sepsis di RSCM pada tahun 2005 (13,86\%), ${ }^{4}$ namun masih lebih rendah dari pada angka kematian neonatus di negara berkembang akibat infeksi yaitu $42 \% .{ }^{1}$ Namun bila dianalisis lebih lanjut, di Divisi Perinatologi IKARSCM neonatus yang meninggal akibat sepsis cenderung 
berkurang setelah dibuka ruang rawat baru (gedung CMU lantai 3) pada 2 Mei 2007. Hal ini terlihat dari hanya 1 subjek sepsis terbukti yang meninggal berasal dari CMU lantai 3, sedangkan lainnya berasal dari ruang rawat lama di IGD lantai 3 (14 subjek), IGD lantai 1 (4 subjek) dan IRNA A lantai 3 (1 subjek).

Acinetobacter calcoaceticus adalah isolat terbanyak, diikuti Staphylococcus epidermidis, Enterobacter aerogenes, Pseudomonas, Eschericia coli dan Klebsiella pneumoniae. Hasil ini hampir sama dengan penelitian Rohsiswatmo $^{12}$ di tempat yang sama pada Juli 2004 - Mei 2005 dengan Acinetobacter calcoaceticus sebagai isolat terbanyak $(35,67 \%)$ diikuti Enterobacter $s p$ (7,01\%), dan Staphylococcus sp (6,81\%).

Laporan dari India juga mengemukakan cenderung meningkatnya profil mikroorganisme tersebut sebagai penyebab sepsis. ${ }^{14,15}$ Mishra $^{14}$ mendapatkan insidens sepsis akibat Acinetobacter adalah 11,1/1000 kelahiran hidup, Acinetobacter merupakan 31,5\% penyebab sepsis neonatorum, diikuti oleh Eschericia coli (26,3\%), Klebsiella pneumoniae $(10,7 \%)$ dan Pseudomonas aeroginosa (7,2\%). Aggarwat ${ }^{16}$ di India mendapatkan Klebsiella pneumoniae sebagai patogen tersering pada sepsis neonatorum (31,2\%-36,4\%), diikuti oleh Staphylococcus aureus (14,3-17,5\%) dan Pseudomonas (13,2\%). Hervas $\mathrm{dkk}^{17}$ mendapatkan pada sepsis awitan lambat Klebsiella pneumoniae dan Staphylococcus epidermidis merupakan isolat yang sering ditemukan pada periode 1977-1991 di Son Dureta University Hospital Spanyol sedangkan pada tahun 1992-1998 yang tersering ditemukan adalah Enterobacter. Rahman ${ }^{18}$ mendapatkan bahwa bakteri gram negatif (Eshericia coli, Pseudomonas, Klebsiella dan Proteus) adalah penyebab utama sepsis neonatorum di Peshawar Pakistan dan Streptokokus grup B tidak ditemukan.

Bakteri gram negatif ternyata juga sering menjadi penyebab sepsis neonatorum di beberapa rumah sakit rujukan di Indonesia. Suarca (2004) ${ }^{19}$ di RS Sanglah Denpasar mendapatkan penyebab tersering adalah Staphylococcus coagulated-negative, Enterobacter sp, dan Klebsiella sp (104 kultur darah positif dari 120 kultur darah). Di RS Hasan Sadikin Bandung, Yuliana (2006) ${ }^{13}$ mendapatkan Staphylococus epidermidis, Burkholderia cepacia, dan Klebsiella pneumoiae sebagai penyebab tersering (53 biakan darah positif dari 80 kultur). Di RS Moh. Husein Palembang, Sofiah $(2006)^{20}$ mendapatkan Acinetobacter calcoaceticus, Klebsiella pneumoniae, Staphylococcus epidermidis, dan Streptococcus viridans sebagai penyebab terbanyak (36 kultur darah positif dari 56 kultur). Rahman ${ }^{21}$ di RS
Sutomo Surabaya mendapatkan penyebab terbanyak adalah Staphylococcus coagulated-negative, Acinetobacter, Enterobacter aerogenes, dan Klebsiella pneumoniae (36 biakan darah positif dari 2416 biakan).

Dijumpai resistensi bakteri gram negatif di bangsal Perinatologi RS Dr. Cipto Mangunkusumo Jakarta terhadap antibiotik meningkat. Rahman ${ }^{18}$ di Pakistan juga mendapatkan kecenderungan peningkatan resistensi terhadap berbagai antibiotik. Hyde dkk. ${ }^{22}$ di San Fransisco dan Atlanta mendapatkan sepsis awitan dini oleh Streptokokus grup B mulai menurun dan sepsis akibat Eshericia coli yang resisten terhadap antibiotik pada bayi prematur cenderung meningkat.

Positivity rate biakan darah kurang memuaskan $(41,2 \%)$, kemungkinan subjek maupun ibu telah mendapat antibiotik sebelumnya telah disingkirkan. Petugas telah mendapat edukasi tentang prosedur pengambilan sampel yang benar. Kemungkinan false negative biakan darah pada subjek yang secara klinis sepsis masih ada karena mungkin masih ada sampel darah yang tidak adekuat akibat kesulitan teknis pengambilan darah pada neonatus, tidak dilakukan biakan untuk bakteri anaerob yang sulit tumbuh pada media biakan, dan penyebab infeksi lain seperti virus, jamur, dan lain lain tidak diteliti. Bakteri anerob (Bacteroides) berperan pada beberapa kasus tersangka sepsis dengan hasil biakan darah negatif yang pada hasil autopsi memang terbukti sepsis. ${ }^{23}$

\section{Kesimpulan}

Sepsis neonatorum umumnya disebabkan oleh bakteri gram negatif dengan isolat terbanyak yaitu Acinetobacter calcoaceticus. Bakteri gram negatif umumnya mempunyai sensitivitas yang rendah terhadap antibiotik lini pertama dan kedua, kecuali Enterobacter aerogenes dan Pseudomonas yang masing-masing sensitif terhadap gentamisin dan seftazidim. Sensitivitas bakteri positif dan negatif umumnya masih sangat baik terhadap meropenem. Sensitivitas bakteri gram negatif cukup baik terhadap imipenem namun bakteri gram positif kurang sensitif terhadap imipenem.

\section{Daftar Pustaka}

1. Aminullah A. Masalah terkini sepsis neonatorum. Dalam Hegar B, Partini PP, Bermansyah EB, penyunting. 
Update in neonatal infection. Jakarta: Departemen Ilmu Kesehatan Anak FKUI-RSCM;2005.h.1-15.

2. Baltimore RS, Huie SM, Meek JI, Schuchat A, O'Brien KL. Early-onset neonatal sepsis in the era of group $b$ streptococcal prevention. Pediatrics 2001; 108:1094-8.

3. Data Rekam Medis Divisi Perinatologi Derpartemen Ilmu Kesehatan Anak, 2005.

4. Rohsiswatmo R. Kontroversi diagnosis sepsis neonatorum. Dalam Hegar B, Partini PP, Bermansyah EB, penyunting. Update in neonatal infection. Jakarta: Departemen Ilmu Kesehatan Anak FKUI-RSCM; 2005.h.32.

5. Orlando Regional Healthcare, Education \& Development. Neonatal sepsis self-learning packet 2002. Diunduh dari http://www.orhs.org/classes/nursing/ sepsis02pdf. Diakses tanggal 30 November 2003.

6. Gotoff SP. Infections of the neonatal infant. Dalam: Behrman RE, Kliegman RM, Jenson HB, penyunting. Textbook of Pediatrics. Edisi ke-16. Philadelphia: WB Saunders; 2000.h.538-52.

7. Stoll BJ, Gordon T, Korones S, Shankaran S, Tyson JE, Bauer CR. Early-onset sepsis in very low birth weight neonates: a report from the national institte of child health and human developmant neonatal research network. J Pediatr 1996;129:72-80.

8. Berry AL, Bellig LL, Ohning BL. Neonatal sepsis. Diunduh dari http://www.emedicine.com/ped/topic2630. htm. Diakses tanggal 12 Oktober 2006.

9. Anonim. Neonatal sepsis. Dalam: Gomella TL, Cunningham MD, Eyal FG, Zenk KE, penyunting. Neonatology management procedures on call problem diseases drugs. Edisi ke-4. New York: Lange Medical Books/McGraw Hill; 1999. h.408-14.

10. Stoll BJ, Gordon T, Korones S, Shankaran S, Tyson JE, Bauer CR. Late-onset in very low birth weight neonates: a report from the national institute of child health and human development neonatal research network. J Pediatr 1996;129:63-71

11. Aminullah A, Rohsiswatmo R, Amir I. Etiology of early and late sepsis in Dr. Cipto Mangunkusumo Hospital (preliminary report). Abstract $12^{\text {th }}$ National Congress of Child Health and $11^{\text {th }}$ Asean Pediatric Federation Conference, Bali; 2002.h.125.(abstrak)

12. Rohsiswatmo R. Multidrug resistance in a neonatal unit and therapeutic implications. Paediatr Indones 2006;46:25-31.
13. Yuliana N, Usman A. Sensitivitas dan spesifisitas pemeriksaan leukosit dan trombosit pada sepsis neonatorum di RSUP Dr. Hasan sadikin Bandung periode Juli-Desember 2006. Dalam: Sadjimin T, Juffrie M, Julia M, Wibowo T, penyunting. Buku Abstrak PIT IKA III-IDAI Yogyakarta: IDAI; 2007.h.27. (abstrak)

14. Mishra A, Mishra S, Jaganath G, Mittal RJ, Gupta PK, Patra DP. Acinetobacter sepsis in newborn. Indian Pediatr 1998;55: 27-32.

15. Christo GG, Shenov V, Mathai J, Shivananda PG, Venkatesh A. Acinetobacter sepsis in neonates. Indian Pediatr 1993;30:1413-6.

16. Aggarwat R, Sarkar N, Deorari A, Paul VK. Indian J Pediatr 2001;68: 1143-7.

17. Hervas J, Ballesteros F, Aloar A, Gil J, Benedi V, Albert $S$. Increase of Enterobacter in neonatal sepsis: a twentytwo-year study. Pediatr Infect Dis J 2001;20:134-40.

18. Rahman S, Hameed, MT Roghani,, Z Ullah. Multidrug resistant neonatal sepsis in Peshawar, Pakistan. Arch Dis Child 2002;87:F52-54.

19. Surca K, Kardana M, Sri Iswari I. Blood culture and sensitivity test pattern of early versus late onset sepsis in neonatal ward Sanglah Hospital Denpasar. Dalam Garna H, Nataprawira HM, penyunting. Abstract Book $13^{\text {th }}$ National Congress of Child Health Konika XIII. Bandung: West Java Indonesian Society of Pediatricians 2005.h.110. (abstrak)

20. Sofiah F, Indra RM, Bermawi H, Tasli JM.Pola sensitivitas kuman penyebab sepsis neonatal terhadap berbagai antibiotik. Dalam Sadjimin T, Juffrie M, Julia M, Wibowo T, penyunting. Buku Abstrak PIT IKA IIIIDAI Yogyakarta: IDAI; 2007.h.30. (abstrak)

21. Rahman T, Utomo MT, Etika R, Indarso F, Harianto A, Damanik SM. Sepsis Neonatorum di RS R. Soetomo surabaya 2006. Dalam Sadjimin T, Juffrie M, Julia M, Wibowo T, penyunting. Buku Abstrak PIT IKA III-IDAI Yogyakarta: IDAI; 2007.h.532. (abstrak)

22. Hyde TB. Hilger TM, Reingold A, Farley MM, O'Brien KL, Schuchat A. Trends in incidence and antimicrobial resistance of early-onset sepsis: population-based surveillance in San Fransisco and Atlanta. Peditrics 2002;110:690-5.

23. Anonim. Neonatal sepsis (sepsis neonatorum). Diunduh dari http://www.merck.com. Diakses tanggal 28 Agustus 2007. 